\title{
COMMENTS
}

\section{ASSUMPTION OF RISK AND VICARIOUS LIABILITY IN PERSONAL INJURY ACTIONS BROUGHT BY PROFESSIONAL ATHLETES}

On June 11, 1979, the Court of Appeals for the Tenth Circuit held in Hackbart $v$. Cincinnati Bengals, Inc. ${ }^{1}$ that a professional football player does not necessarily assume all risks of personal mjury merely by participating in the game. ${ }^{2}$ The lower court, ${ }^{3}$ in holding to the contrary, had concluded that "NFL rules of play are so legahistic . . . [and the game is so fast] that the differences between violations which could fairly be called deliberate, reckless or outrageous and those which are 'fair play' would be so sinall and subjective as to be incapable of articulation." 4 From this analysis, the district court had determined that it should not hear the case. The court of appeals reversed the district court decision ${ }^{5}$ and reinanded the case for trial. ${ }^{6}$

Ten weeks later, a jury in a federal district court awarded Houston Rockets professional basketball player Rudy Tomjanovich $\$ 3.25$ million $^{7}$ in his suit against the Los Angeles Lakers for injuries he suffered

1. 601 F.2d 516 (10th Cir.), cert. denied, 444 U.S. 931 (1979).

2. 601 F.2d at 520-21. The court rejected the view that the football field is "like a battlefield where the restraints of civilization have been left on the sidelines." Id. at 520 .

3. Hackbart v. Cincinnati Bengals, Inc., 435 F. Supp. 352, 356 (D. Colo. 1977), rev'd, 601 F.2d 516 (10th Cir.), cert. denied, 441 U.S. 931 (1979).

4. $435 \mathrm{~F}$. Supp. at 358 . As a matter of social policy the district court ruled that professional football is an area best left to the supervision of the legislature. It analogized the hazards of professional football to those inherent in coal mining and railroading, and suggested that legislation along the limes of the Federal Coal Mining Safety Act and the Federal Employers' Liability Act would be the most appropriate way to handle tort liability in professional football. $/ d$. at 357. The court notcd that the commercial nature of the game made professional football a particularly "dense thicket," with which the courts should avoid entanglement. Id. at 358.

5. 601 F.2d at 524.

6. The appellees filed a writ of certiorari with the Supreme Court seeking review of the circuit court's decision that there was jurisdiction over the case. Certiorari was denicd, 441 U.S. 931 (1979).

7. Tomjanovich v. California Sports, Inc., No. 78-243 (S.D. Tex. Oct. 10, 1979), appeal docketed, No. 79-3889 (5th Cir. Dec. 3, 1979). The jury awarded $\$ 21,376$ for past medical expenses; $\$ 200,000$ for future medical expenses; $\$ 100,000$ for past physical pain; $\$ 100,000$ for future physical paim; $\$ 200,000$ for past mental anguish; $\$ 75,000$ for future mental anguish; $\$ 150,000$ for loss of earnings (even though Tomjanovich received his salary while injured); $\$ 850,000$ for loss of future earning capacity; $\$ 50,000$ for his wife's loss of comfort (she was also a plaintiff in the aetion); and $\$ 1,500,000$ for punitive damages. The total award excceded by $\$ 600,000$ the amount sought by Tomjanovich. The National Law Journal, Sept. 3, 1979, at 13, col. 3. 
when a Lakers employee, Kermit Washington, struck him in the face during a game. ${ }^{8}$ The Tomjanovich case was the first successful civil damages action ever brought by a professional athlete against an opponent or an opposing team.

Decided within several inonths of each other, the Tomjanovich and Hackbart cases may indicate a new, activist trend by the judiciary in the area of professional sports. This Comment will examine these two cases, particularly Hackbart, to determine whether this trend represents a radical departure froin prior law, or is simply an incremental step in a changing area of law. The Cominent will begin by examining the assumption of risk defense to determine why this traditional bar to recovery for sports injuries ${ }^{9}$ no longer defeats a cause of action for such injuries as a matter of law. The first section will also analyze the history of both the assumption of risk defense and tort litigation in sports. The following section will discuss whether a team should be held liable for the tortious conduct of its employees. This issue raises a perplexing question: if a plaintiff has not assumed the risks which led to his injury because the defendant's actions are outside the scope of the rules and customs of the game, can the defendant's tortious conduct still be within the scope of his employment ${ }^{10}$ so that his employer will be liable?

\section{Violence in Professional Sports}

\section{A. Hackbart v. Cincinnati Bengals, Inc. ${ }^{11}$}

On September 16, 1973, the Cincinnati Bengals and the Denver Broncos played a football game in Denver, Colorado. With the score at 21 to 3 in Denver's favor, the Broncos intercepted a Cimcinnati pass. Bengals running back "Booby" Clark, "acting out of anger and frustration, but without a specific intent to injure," 12 reacted by delivering a forearm blow to the back of Bronco's defensive back Dale Hackbart's neck. No penalty was called, and no altercation ensued. Hackbart subsequently suffered soine pain but continued playing for two more weeks, after which the teain released him. Hackbart eventually sought inedical attention, and his injury was diagnosed as a fractured neck. ${ }^{13}$

8. Washington was not made a party to the suit.

9. See notes 25-34 infra and accompanying text.

10. See generally RESTATEMENT (SECOND) OF AGENCY $\$ 228$ (1958).

11. 601 F.2d 516 (10th Cir. 1979), cert. denied, 444 U.S. 931 (1979).

12. $435 \mathrm{~F}$. Supp. at 353 . Clark testified that he was frustrated because the Bengals were losing the game. 601 F.2d at 519 .

13. Federal District Judge Richard Matsch, sitting without a jury, found these to be the facts. They appear never to have been controverted. No referee saw Clark deliver the blow, but game 
Hackbart then instituted an action against the Cincinnati Bengals and Clark.

The Colorado district court held that Hackbart had assumed the risk ${ }^{14}$ of his injury and could not maintain an action:

Upon all of the evidence, my finding is that the level of violence and the frequency of emotional outbursts in NFL football games are such that Dale Hackbart must have recognized and accepted the risk that he would be injured by such an act as that committed by the defendant Clark ....15

The district court also analyzed the problem from a duty-of-care perspective, and rejected the notion that a professional football player owes a duty of care to an opponent. ${ }^{16}$ Thus, relying upon assumptionof-risk and duty-of-care analyses, the court concluded that Clark was not liable for his conduct; even if he did owe Hackbart a duty to conduct himself in a reasonable inanner, Hackbart assuined the risk that lie would not do so. ${ }^{17}$

Having established the defendants' nonliability, ${ }^{18}$ the district court went on to reject judicial interference in professional football generally. ${ }^{19}$ It is unclear why the court felt obligated to discuss the social pohicy underlying the inapplicability of traditional tort principles to professional football. ${ }^{20}$ Since the court had already rejected the plaintiff's claim, enunciating a judicial policy of nonintervention was unnecessary to the decision. Not surprisingly, the Court of Appeals for the Tenth Circuit unambiguously rejected this approaclı. ${ }^{21}$

films clearly show the incident. $601 \mathrm{~F} .2 \mathrm{~d}$ at 519 . The Broncos intercepted a Bengals pass, and Hackbart attempted to block Clark to prevent Clark from tackling his teammate. Hackbart fell to the ground and Clark hit him from behind.

14. For a general discussion of assumption of risk, see W. Prosser, LAW OF TORTS $\S 68$ (4th ed. 1971).

15. 435 F. Supp. at 356 . The court heard testimony of former football players condeanning the incident as outside the customs of the game, 601 F.2d at 521 , but did not view this evidence as dispositive.

16. 435 F. Supp. at 356. The court einphasized the violent nature of the game, and stated: It is wholly incongruous to talk about a professional football player's duty of care for the safety of opposing players when he has been trained and motivated to be heedless of injury to himself. The character of NFL competition negates any notion that the playing Id. conduct can be circumscribed by any standard of reasonableness.

17. Id.

18. Naturally, the Bengals could not be liable as Clark's employer if Clark himself was not. See Restatement (SECOND) of AgEnCy \& 217A (1958); Restatement of Judgments \$ 99(3) (Tent. Draft No. 4, 1977).

19. See note 4 supra and accoinpanying text.

20. 435 F. Supp. at 357.

21. The court stated:

The [district] judge also pointed out that courts are ill-suited to decide the different social questions and to adininister conflicts on what is much like a battlefield where the re- 
B. Tomjanovich v. Cahfornia Sports, Inc.22

The Tomjanovich case arose out of an altercation between Kevin Kunnert of professional basketball's Houston Rockets and Kernit Washington of the Los Angeles Lakers. Tomjanovich, a Houston player, attempted to break up the fight. Washington, seeing this opponent approaching rapidly, and not aware of his purpose, turned and hit Tomjanovich. The blow fractured Tounjanovich's face and skull, broke his nose, separated his upper jaw, and caused a cerebral concussion. Washington was fined $\$ 10,000$ and was suspended for at least sixty days-the stiffest punishınent ever imposed by National Basketball Association Commissioner Larry O'Brien. Several teammates reportedly were unhappy with the severity of the penalty. They sympathized with Washington's reflex action at seeing a perceived enemy approaching, and noted that Washington was not considered a "dirty" player. ${ }^{23}$

Violence in professional sports is not a new phenomenon. The Tomjanovich and Hackbart cases, however, werc attempts to find a new answer to this old problem. Injured by acts of violence, Tomjanovich and Hackbart sought judicial relief. That they pursued suclı a course was in itself historic; that Tomjanovich actually won ${ }^{24}$ prompts an exammation of the doctrine of assumption of risk-which for so long precluded such victories-and of its demise.

\section{Assumption of Risk}

\section{A. Early History.}

The defense of assumption of risk ${ }^{25}$ traditionally has prevented plaintiffs fronl succeeding in suits for sports imjuries when they con-

straints of civilization have been left on the sidelines.

We are forced to conclude that the result reached [by the district court] is not supported by evidence. 601 F.2d at 520 .

It is difficult to understand why social policy should dictate judicial blindness to the violence of professional football. The threat of proper judicial intervention can serve the useful function of discouraging uncontrolled and unnecessary violence. To say that there will be many cases which are best decided on the field rather than in the courtroom is not to say that the oceasional blatant violation of both the regulations of the league and the laws of the states should not be heard by the judiciary.

22. No. 78-243 (S.D. Tex. Oct. 10, 1979), appeal docketed, No. 79-3889 (5th Cir. Dec. 3, 1979).

23. Kirkpatrick, Shattered and Shaken, SPORTS IlluSTRATED, Jan. 2, 1978, at 47. For a brief account of the trial see notes 7-8 supra and accompanying text.

24. A final decision has not yet been reached in the Hackbart case.

25. The RESTATEMENT (SECOND) OF TORTS $\$ 496 C$ (1965) defines assumption of risk thus:

(1) . . . a plamtiff who fully understands a risk of harm to himself . . . caused by the defendant's conduct. . ., and who nevertheless voluntarily chooses to enter or reinain 
sented ${ }^{26}$ to participating in competition. One of the first cases to bar a plaintiff's action because he was held to have assumed the risk of his injury was Murphy v. Steeplechase Amusement Co.27 In Murphy, the plaintiff was charged with the knowledge that people frequently fell while on the particular annusement park attraction on which he was injured. The court noted that "[o]ne who takes part in such a sport accepts the dangers that inhere in it so far as they are obvious and necessary . . .."28 That the plaintiff's fall led to an unusually severe injury was immaterial because the assuinption of the risk of the fall itself barred the action. Interestingly, the court also suggested that the defendant was not negligent. The amusement attraction was not found to have hidden defects, or to have been running irregularly. ${ }^{29}$ If the defendant was not negligent, however, he could not be found liable even if the plaintiff had not assumed any risks. Thus, although Murphy is often cited as an example of the operation of an assumption of risk defense, the case may also have been decided on the ground that the defendant was nonnegligent because he did not violate any duty of care owed to the plaintiff. Of course, a reasonable interpretation of the court's use of both the assumption of risk and the duty of care principles is that the defendant was nonnegligent because of the plaintiff's assuinption of risk. That is, the defendant's duty of care was reduced to the extent that the plaintiff assuined certain risks. This would inversely relate negligence and assumption of risk on a continuum-the more risk assuined, the less care owed. Whether the Murphy court relied on this reasoning is unclear.

A coinparison of Murphy with the New York case of Tantillo $v$. Goldstein Bros. Amusement Co., ${ }^{30}$ decided one year earlier, suggests the limited extent to which the Murphy court may have relied on the assumption of risk doctrine. In Murphy, Chief Judge Cardozo dist-

.. . within the area of that risk, under circumstances that manifest his willingness to accept it, is not entitled to recover for harm within that risk.

The key elements are knowledge, and voluntary assumption, of the risk. See id. $\$ \S 496 \mathrm{~A}, 496 \mathrm{D}$, and 496E. For an early elucidation of the doctrine, see Bohlen, Voluntary Assumipion of Risk, 20 HARV. L. REv. 14 (1906). See also Symposium: Assumption of Risk, 22 LA. L. REv. 1 (1961).

26. Consent has been defined as a "willingness in fact for conduct to occur." RESTATEMENT (SECOND) OF TORTS $\$ 892$ (1965). An early case barring the plaintiff from recovery is McAdams v. Windham, 208 Ala. 492, 94 So. 742 (1922), in which a friendly boxing match resulted in the death of one of the participants. The court held that the deadly blow had been consented to and was therefore not actionable. Id. at 493,94 So. at 743 .

27. 250 N.Y. 479,166 N.E. 173 (1929).

28. Id. at 482,166 N.E. at 174 .

29. Id.

30. 248 N.Y. 286,162 N.E. 82 (1928). The plaintiff, a minor, was admitted without charge to a vaudeville show and induced to participate in one of the acts. Because of the troupe's negligence, the plaintiff's arm was broken. 
inguished Tantillo as a case in which the risks were "obscure or unobserved," 31 and therefore not assumed. The Tantillo court held that the plaintiffs, though voluntary participants, were entitled to be protected froin dangers inherent in a vaudeville act. The court did not, however, decide whether these dangers were "obvious" or "obscure." 32 The issue of assumption of risk, seemingly a relevant defense in the case, was never raised. In Tantillo, even though the plaintiff voluntarily participated in the vaudeville act, the defendant's duty of care was not reduced. When the defendant violated his duty, he was hable. The assunption of risk defense was therefore of uncertain utihty: the court decided Tantillo without reference to that defense, and a pure negligence analysis, ignoring assumption of risk, could have decided Murphy as well.

In McLeod Stores v. Vinson, ${ }^{33}$ however, a Kentucky court left no doubt that it relied on the assumption of risk defense as a bar to a plaintiff's recovery. Vinson had sued McLeod Stores for injuries sustained during his voluntary participation in a contest the store held on a public street. The court distinguished between the duty of care owed by the store to Vinson as a participant, and that owed to a mere passerby. The latter was entitled to protection from risks inherent in the contest. Vinson, on the other hand, had assumed such risks by participating and hence was not entitled to the same protection. ${ }^{34}$ Whether the store was neghigent in running its contest was of no significance. In essence, the court held that Vinson waived some of the store's negligence when he entered the contest: "Assumption of risk is in effect a waiver of defects and dangers ....."3s This case, then, more clearly than the New York cases of Murphy and Tantillo, presents an assumption of risk analysis that bars participants from recovering for personal injuries caused by dangers obvious and inherent in an activity. It demonstrates more precisely that the duty of care a defendant owes is related to the risks a plaintiff assumes.

31. Murphy v. Steeplechase Amusement Co., 250 N.Y. at 483, 166 N.E. at 174.

32. 248 N.Y. at 288,162 N.E. at 83 . This case served as the basis for Judge O'Brien's dissent in Murphy. 250 N.Y. at 484, 166 N.E. at 175.

33. 213 Ky. 667, 281 S.w. 799 (1926).

34. The court held that "in entering the race [Vinson] assumed the ordinary risks incident thereto and is thereby barred of recovery in this action." Id. at 670,281 S.W. at 800 .

35. Id. at 669, 281 S.W. at 800 (quoting Cincinnati, N.O. \& T.P. Ry. v. Goldston, 156 Ky. 410,161 S.W. 246 (1913)). Perhaps the best way to approach this topic is to say that assumption of risk, in its simplest form, reduces but does not eliminate a defendant's duty of care. When the reduced duty is violated, the defendant will be liable in the absence of other defenses. Assuinption of risk determines when some degree of care less than the degree normally owed is nonetheless sufficient to bar hability. Tavernier v. Maes, 242 Cal. App. 2d 532, 545, 51 Cal. Rptr. 575, 583 (1966). 
McLeod Stores, however, is not in line with most of the other early cases in the sports and games area. ${ }^{36}$ Rather, Murphy and Tantillo, with their confused analyses of assumption of risk and duty of care, better represent this period. Judicial confusion has led to imprecision in legal commentary. One writer, ${ }^{37}$ for example, has cited the case of Toohey $v$. Webster ${ }^{38}$ for the proposition that "courts addressing tort liability in athletic contests have recognized the existence of both contributory negligence and assumption of the risk as appropriate defenses." 39 Yet im Toohey, the court held for the plaintiff, stating that the defendant had a duty of care to warn the plaintiff of the risk involved. The court flatly rejected the defense of assumption of risk, "having already decided that it was the duty of the defendant to give audible and timely warning ...."40 The court refused to recognize the assumption of risk defense in cases $m$ which the defendant is ncgligent; when the defendant is not negligent the defense is, of course, unnecessary. Unlike McLeod, Toohey did not distinguish between individuals who had and had not assumed certain risks, apparently deciding that the risk of a defendant's neghigence cannot be assumed by a plaintiff and hence is always actionable. The court did not even consider whether a defendant's duty of care can be reduced by any assumption of risk.

The early cases thus demonstrate the various approaches courts have taken in applying the assumption of risk defense. While some courts have used the defense to reduce the duty of care owed, ${ }^{41}$ other courts have determined the defendant's liability by a simple negligence analysis without regard to the defense of assumption of risk. ${ }^{42}$ This confusion is not surprising. Indeed, many commentators argue that assumption of risk is a defense without a purpose, an obfuscation best left out of the law of torts. ${ }^{43}$ Their argument generally divides assumption

36. For a general treatment of liability for sports injuries see J. WEISTART \& C. LOWELL, THE LAW OF SPORTS ch. 8 (1979). For a collection of both early and more recent assumption of risk cases see id. 935 n.24. See also McAdams v. Windham, 208 Ala. 492, 94 So. 742 (1922); Freedman v. Hurwitz, 116 Conn. 283, 164 A. 647 (1933); Goldstein v. United Amusement Corp., 86 N.H. 402, 169 A. 587 (1933); Thomas v. Barlow, 5 N.J. Misc. 764, 138 A. 208 (1927).

37. 12 GA. L. REv. 380 (1978).

38. 97 N.J.L. 545, 117 A. 838 (1922). The plaintif, a minor, was a caddy on a golf course when injured by a ball hit from an adjacent fairway. The golfer was in the rough and had to hit over the green near which the plaintiff was rightfully standing.

39. 12 GA. L. Rev. 380, 384 n.18 (1978).

40. 97 N.J.L. at 549,117 A. at 839.

41. See notes 34-35 supra and accompanying text.

42. See notes 29-32 supra and accompanying text.

43. See generally 2 F. HARPER \& F. JAMES, LAW OF TORTS ch. XXI (1956); Bohlen, supra note 25; James, Assumption of Risk: Unhappy Reincarnation, 78 Y ALE L.J. 185 (1968). But see W. 
of risk cases into two categories: (1) those in which the plaintiff reasonably assumed the risk, and (2) those im which the plaintiff unreasonably assumed the risk. Proponents of abolishing the defense argue that the first category can simply be subsumed under a duty of care analysis, and that the second category involves nothing inore than contributory neghigence. ${ }^{44}$ Although eliminating the use of the phrase "assumption of risk" would help alleviate the confusion generated by cases such as Murphy, Tantillo, and Toohey, it would not completely solve the problem. For example, cases in which the parties explicitly agree upon the assumption of risk do not fit into either of the two groups. The phrase would still be needed, therefore, albeit in a more limited role. Professor John Wade, former dean of Vanderbilt University School of Law, finds further fault with abolishing the defense: recognizing the problems inherent in the use of "assumption of risk," he contends that the phrase nevertheless has certain advantages-principally "forensic and administrative." 45 Wade argues that the defense gives a court greater flexibility in negligence cases, and generally does not force the court to reach a "wrong" conclusion. ${ }^{46}$

The first scholarly writing on assumption of risk expresses doubt about the validity of that defense as a separate doctrime. In his seminal article, Professor Francis H. Bohlen apparently argued that assumption of risk is inerely another way of discussing duty of care. ${ }^{47}$ This is most evident in his interpretation of Priestly v. Fowler, ${ }^{48}$ generally cited as the first assumption of risk case. Bohlen viewed the case wliolly froin a duty of care perspective. ${ }^{49}$ The plaintiff servant in Priestly was denied

Prosser, supra note 14, at 454-57; Wade, The Place of Asstumption of Risk in the Law of Negligence, 22 LA. L. REv. 5, 14-15 (1961).

44. 2 F. HARPER \& F. JAMES, supra note 43, at 1162.

45. Wade, supra note 43 , at 14.

46. Id. James maintains that Wade disagrees with his view of assumption of risk. James, Assumption of Risk, supra note 43, at 185 n.3. The gulf between them, however, is not very wide. Wade freely acknowledges the disadvantages of the phrase and admits that "[a]ccurate analysis .. . would probably be advanced if the term [assumption of risk] were eradicated . . . ." Wade, supra note 43 , at 14 . The difference is that James urges that the phrase be ehiminated while Wade recognizes its deeply rooted attachment to the law and the unlikehihood of its demise.

47. Bohlen, supra note 25, at 18. Although James imterprets Bohlen in this manner, his reasoning is unclear. James, Assumption of Risk, stupra note 43, at 185-86. While Bohlen claims that contributory negligence and assumption of risk can be viewed as distinct concepts, their merger is, in the typical case, inevitable under his analysis. Bohlen, stupra note 25 , at 18 .

48. $3 \mathrm{M} \& \mathrm{~W} 1$ (1837). See Bohlen, supra note 25, at 27 for a discussion of this case.

49. Bohlen served as reporter for the first Restatement of TORTS. During his tenure, the RESTATEMENT did not include a separate defense of assumption of risk. Section 893 of the RESTATEMENT, which does establish a separate defense, was introduced only after Bohlen left his position. See Wade, supra note 43, at 6 . Wade believes that Bohlen, when writing his article, believed that assumption of risk warranted a separate defense but changed his mind before becoming Restatement Reporter. Id. James, on the other hand, beheves that Bohlen was consist- 
recovery from his employer because the employer did not owe a duty to the servant greater than the duty owed by the servant to himself. ${ }^{50}$ The first assumption of risk article, discussing the first assumption of risk case, thus rehed heavily on a duty of care analysis. ${ }^{51}$ Confusion over the application and utility of a separate assumption of risk analysis is a natural legacy of this beginning. 52

\section{B. Recent History.}

Out of this confusion the Restatement (Second) of Torts developed a formalized definition of assumption of risk..$^{53}$ The Restatement takes the position that plaintiffs who knowingly ${ }^{54}$ and voluntarilys5 enter into

ently opposed to any separate assumption of risk “doctrine." James, Assumption of Risk, supra note 43 , at 185 n.3.

50. A similar philosophy was expressed in Eckert v. Long lsland R.R., 43 N.Y. 502, 507 (1871) (Allen, J., dissenting).

51. If the plaintiff is willing to subject himself to certain risks, the defendant should not be liable for exposing the plaintiff to those risks. This is what is meant by stating that the defendant does not owe the plaintiff a higher standard of care than the plaintiff owes himself. Accordingly, the plaintiff who has assumed a risk is owed a lesser duty of care than one who has not. This approach gives some credence to the criticism leveled at the assumption of risk defense: it is so closely tied to duty of care that it cannot be treated separately.

52. See text accompanying notes 41-44 supra. The confusion may be alleviated by noting that assumption of risk problems arise in two situations: first, where the plaintif acts before the defendant, and second, where the plaintiff acts after the defendant. It is in the second category that the breach of duty and assumplion of risk theories become entangled, for while the defend. ant's act may be a breach of duty, the plaintiff may assume the risks presented by the breach and be barred from recovery. Those who attack the doctrine argue that whereas the plaintiff's actions in assuming the risk may be reasonable, and therefore not contributorily negligent, a defendant found to be negligent for having breached what would normally be his duty can avoid liability with an assumption of risk defense. If the duty of care analysis is used, however, a more equitable decision will be reached. See Mansfield, Informed Choice in the Law of Torts, 22 LA. L. REv. 17, 21-22, 63 (1961).

53. Restatement (Second) of Torts $\$ \$ 496$ A-496E (1965). Section 496A defines the defense: "A plaintiff who voluntarily assumes a risk of harm arising from the negligent or reckless conduct of the defendant cannot recover for such harm."

54. Scction $496 \mathrm{C}$ provides:

Implied Assumption of Risk.

(1) Except as stated in Subsection (2), a plaintiff who fully understands a risk of harm to himself or his things caused by the defendant's conduct or by the condition of the defendant's land or chattels, and who nevertheless voluntarily chooses to enter or remain, or to permit his things to enter or remain within the area of that risk, under circumstances that manifest his willingness to accept it, is not entitled to recover for harm within that risk.

(2) The rule stated in Subsection (1) does not apply in any situation in which an express agreement to accept the risk would be invalid as contrary to public policy. Id. $\$ 496 \mathrm{c}$.

55. Section 496E provides:

Necessity of Voluntary Assumption.

(1) A plaintiff does not assume a risk of harm unless he voluntarily accepls the risk. 
an area of risk should not recover for injuries sustained because of that risk. ${ }^{56}$ Mere knowledge of the risk is not sufficient under the Restatement. The plaintiff must "appreciate the danger itself and the nature, character, and extent which makes it unreasonable," 57 and assume the risk voluntarily. ${ }^{58}$ In other words, the plaintiff must voluntarily take his chances of injury, and if he is injured because of the particular risks of which he was actually aware, he cannot recover. The Restatement thus distinguishes the defense of contributory neghigence, which relies on a reasonable inan standard (an objective standard) ${ }^{59}$ from the assumption of risk defense, which einploys a subjective standard. ${ }^{60}$

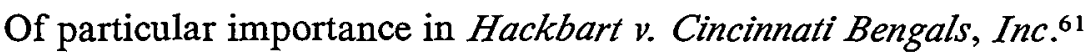
is the notion that to be barred from recovery, the plaintiff inust have assumed the specific risks that led to his injury. In each case the chances the plamtiff was willing to take inust be compared with the mjury sustained to determine whether that injury is within the area of assumed risk.

Skatimg injuries present a good example of the specificity requirement. In Moe v. Steenberg, ${ }^{62}$ the plaintiff, while ice skating, collided with the defendant, who had been skating backwards. In affirming a verdict for the defendant based on an assumption of risk defense, the court held, "It is the general rule that one who participates in a sport assumes the risks which are inherent in it, and it is ordinarily for the

(2) The plaintif's acceptance of a risk is not voluntary if the defendant's tortious conduct has left him no reasonable alternative course of conduct in order to

(a) avert harm to himself or another, or

(b) exercise or protect a right or privilege of which the defendant has no right to deprive him.

Id. $\$ 496 \mathrm{E}$.

56. See note 53 supra.

57. Restatement (SECOND) OF ToRTs $\$ 496 \mathrm{D}$, comment b (1965). Section 496D provides:

Knowledge and Appreciaton of Risk.

Except where he expressly so agrees, a plaintiff does not assume a risk of harm arising

from the defendant's conduct unless he then knows of the existence of the risk and appreciates its unreasonable character.

58. Id. Section $496 \mathrm{E}$ states: “A plaintiff does not assume a risk of harm unless he voluntarily accepts the risk." Knowledge and willingness have always been required as elements of the defense. See Thomas v. Quartermaine, 18 Q.B.D. 685 (1887): "The maxim, be it observed, is not 'scienti non fit injuria,' but 'volenti.' It is plain that mere knowledge [of the risk] may not be a conclusive defense." Id. at 696 . The defendant must prove the willingness of the plaintiff as well.

59. Restatement (SeCOND) of TORTS $\$ \$ 289-290,464$ (1965). See Maxey v. Freightliner Corp., 450 F. Supp. 955, 961 (N.D. Tex. 1978); McGowan v. St. Regis Paper Co., 419 F. Supp. 742, 746 (S.D. Miss. 1976).

60. Maxey v. Freightliner Corp., 450 F. Supp. at 961; McGowan v. St. Regis Paper Co., 419 F. Supp at 746. See Schrader v. Kriesel, 232 Minn. 238, 247, 45 N.W.2d 395, 400 (1950); Landrum v. Roddy, 143 Neb. 934, 944-47, 12 N.W.2d 82, 88-89 (1943).

61. 601 F.2d 516 (10th Cir.), cert. denied, 444 U.S. 931 (I979).

62. 275 Minn. 448,147 N.W.2d 587 (1966). 
jury to determine what those risks are."63 In this case, the jury determined that an inexperienced skater could expect to fall occasionally and hence assumed the risk that other skaters, especially one skating backwards, might trip over him. ${ }^{64}$ In a somewhat similar case, Schamel v. St. Louis Arena Corp. ${ }^{65}$ however, the court reached a different result. In Schamel, the plaintiff was hit by a person whose skating violated rink rules. The court affirmed a verdict for the plaintiff, ${ }^{66}$ emphasizing that the other skater's violation of the rules had continued long enough for the rink guard and management to have stopped him. The court expressly rejected an assumption of risk defense. ${ }^{67}$

The collisions in these two cases were similar, but the holdings are different. One explanation for this difference may be that in Schamel, unlike Steenberg, the plaintiff sued the rink proprietor, and not another skater. A jury may have been less hesitant to hold the arena liable than to find against a skater who was probably uninsured. In both cases, however, the court relied on an assumption of risk analysis. In Steenberg, a collision with a skater moving backwards was found to be inherent in the sport, whereas im Schamel, a colhsion with a reckless violator of the rules, left uncontrolled by management, was not. The effect that safety rule violations have on the assumption of risk defense

\footnotetext{
63. Id. at 450,147 N.W.2d at 589 (citations omitted).

64. Id. at 451,147 N.W.2d at 589.

65. 324 S.W.2d 375 (Mo. Ct. App. 1959).

66. Id. at 378 .

67. She assumed risks that were inherent in the sport or amusement in which she was engaged, such as falls and collisions with other skaters brought about by her own or other skater['s] lack of skill or clumsiness. Such things are not extraordinary occurrences in skating rinks. But she did not assume any extraordmary risks caused by the obvious misconduct of other patrons which could have been detected and controlled by the defendant.
}

Id. (citation ounitted). The offending skater had violated the rink rules by skating too fast and weaving in and out aunong the other skaters.

Another case rejecting the assumption of risk defense is Hawayek v. Simmons, 91 So. $2 \mathrm{~d} 49$ (La. App. 1956), in which the plaintiff fisherman was injured by a lure cast by his coinpanion. The court, though noting that a participant in a sport "assumes all risks incidental . . . and foreseeable," id. at 53, held that the plaintiff had not assumed "all risks of negligence of those other persons in the fishing party." Id. at 54. Since the miscast lure was not inherent to the sport, it was not a risk assuined by the plaintiff.

Cases in which the risk has been held to have been assumed, and recovery barred, include Tavernier v. Maes, 242 Cal. App. 2d 532, 51 Cal. Rptr. 575 (1966) (a second baseman's ankle was broken by a lard slide); Richmond v. Employers' Fire lns. Co., 298 So. 2d 118 (La. App.) (a college baseball player was hit by a bat which slipped out of the hands of an assistant coach), cert. denied, 302 So. 2d 18 (La. 1974); Gaspard v. Grain Dealers Mutual lns. Co., 131 So. 2d 831 (La. App. 1961) (the plaintiff was struck by a bat which slipped from the defendant's hands during school recess); McGee v. Board of Educ., 16 A.D.2d 99, 226 N.Y.S.2d 329 (1962) (a teacher was hit by a ball thrown froin first to third base while he was instructing a pitcher on the pitcher's mound). 
will be discussed below, ${ }^{68}$ but it is important to note here the fundamental poimt that "assumption of risk" does not mean assumption of all risks. Negligent activity outside the scope of assumed risk is undoubtedly actionable. ${ }^{69}$ That the plaintiff must have assumed the specific risk that led to his injury in order to be barred from recovery reduces the utility of the defense and makes it correspondingly easier for a plaintiff to recover.

\section{The Modern Trend.}

In recent years, assumption of risk has been less effective as a defense in sports injury cases. An important case demonstrating this declime is Nabozny v. Barnhill..$^{70}$ The plaintiff in Nabozny, a minor, received serious injuries while playing goalkeeper in a soccer match. He was kicked in the liead by an opponent who, im violation of the game's rules, pursued the ball after the plaintiff liad picked it up. Speaking wholly in terms of duty of care, the Nabozny court framed the issue in the case as "whether the imterest of the plaintiff which has suffered invasion was entitled to legal protection at the hands of the defendant." 71

The court rejected the defendant's theory that a participant assumes the risk of any injury he might receive during the course of a game. Reversing a lower court's directed verdict for the defendant, ${ }^{72}$ the court empliasized the defendant's violation of a known safety rule ${ }^{73}$ and concluded that deliberate or reckless disregard for rules proscribing certain conduct cannot be accepted as part of the game. The $\mathrm{Na}$ bozny court's reasoning - that participants im games do not assume the risk that safety rules will be violated-is, at first blusli, easily incorpo-

68. See notes 73-76 infra and accompanying text.

69. One New York court summed up this point well by noting:

Generally, the participants in an athletic event are held to have assumed the risks of injury normally associated with the sport . . . . Players, coaches, managers, referees and others who, in one way or another, voluntarily participate must accept the risks to which their roles expose them. Of course, this is not to say that actionable negligence can never be committed on a playing field .... [A] participant's conduct may amount to such careless disregard for the safety of others as to create risks not fairly assumed.

McGee v. Board of Educ., 16 A.D.2d at 101-02, 226 N.Y.S.2d at 331-32. This is a far more sophisticated view of assumption of risk than was present in the earlier cases in this area.

70. 31 Ill. App. 3d 212, 334 N.E.2d 258 (1975).

71. Id. at 214, 334 N.E.2d at 260 (citing W. Prosser, supra note 14, at 206).

72. 31 Ill. App. 3d at 216, 334 N.E.2d at 261. The court held that "It is our opinion that a player is liable for injury in a tort action if his conduct is such that it is either deliberate, wilful or with a reckless disregard for the safety of the other player . . ." Id. at 215,334 N.E.2d at 261.

73. In soccer, a player may not make contact with a goalkeeper who is within the penalty area. Id. at 215, 334 N.E.2d at 260-61. See ResTATEMENT (SECOND) OF TorTs § 50, comment b (1965). 
rated into an assumption of risk approach. Essentially, this is the approach taken in comment $\mathrm{b}$ to section 50 of the Restatement (Second) of Torts. Comment b, discussed by the Nabozny court, ${ }^{74}$ states that violations of safety rules are actionable even if such violations are frequent and foreseeable. ${ }^{75}$ The traditional assumption of risk doctrine, however, precludes recovery for injuries resulting from foreseeable violations. ${ }^{76}$ Thus the Nabozny court, in adopting section 50, rejected the traditional assumption of risk doctrine as being too harsh on the plaintiff. ${ }^{77}$

In Bourque v. Duplechin, too, the court rejected the traditional assumption of risk doctrine and held that

[a] participant in a game or sport assumes all of the risks incidental to that particular activity which are obvious and foreseeable. A participant does not assume the risk of injury from fellow players acting in an unexpected or unsportsmanlike way with a reckless lack of concern for others participating. ${ }^{78}$

Although the Bourque holding is grounded on assumption of risk principles, the court reduced considerably the area of obvious and foreseeable risks. In Bourque, a 1977 case, a collision five feet froin second base in a competitive baseball game was held not to be a foreseeable risk. Ten years earlier, however, a California court had held that a hard slide into second base in a family gaine was foreseeable even if players seldoin slid. ${ }^{79}$ The trend is clear. ${ }^{80}$ Bourque reduced the area

74. 31 Ill. App. $3 d$ at 215,334 N.E.2d at 260-61.

75. The comment states:

Taking part in a game manifests a willingness to submit to such bodily contacts or restrictions of liberty as are permitted by its rules or usages. Participating in such a game does not manifest consent to contacts which are prohibited by rules or usages of the game if such rules or usages are designed to protect the participants and not merely to secure the better playing of the game as a test of skill. This is true although the player knows that those with or agamst whom he is playing are habitual violators of such rules.

Restatement (SECOND) OF TORTS $\& 50$, comment b (1965).

76. See text accompanying note 28 supra.

77. The rejection of the assumption of risk defense is by no means limited to sports litigation. Several states have abolished the doctrime outright. See, e.g., Parker v. Redden, 421 S.W.2d 586 (Ky. 1967); Felgner v. Anderson, 375 Mich. 23, 133 N.W.2d 136 (1965) (with some exceptions); Bolduc v. Cram, 104 N.H. 163, 181 A.2d 641 (1962); Meistrich v. Casino Arena Attractions, Inc., 31 N.J. 44, 155 A.2d 90 (1959) (first jurisdiction to abolish the defense as a separate doctrine).

78. 331 So. 2d 40, 42 (La. App. 1976). The plaintiff in Bourque was a second baseman in a competitive baseball game and the defendant was a baserunner. A collision occurred when the plaintiff was over five feet from the base and had already released the ball. The court did not require the defendant to be guilty of reckless misconduct before it would hold him liable. Rather, ordmary negligence was sufficient for liability to attacl. See id. at 43. Contra, Nabozny v. Barnhill, 31 Ill. App. 3d at 215, 334 N.E.2d at 261. Assumption of risk is a defense against both negligence and reckless misconduct. RESTATEMENT (SECOND) OF TORTS $\$ 503$ (1965).

79. Tavernier v. Maes, 242 Cal. App. 2d 532, 51 Cal. Rptr. 575 (1966).

80. See Ceplina v. Soutl Milwaukee Sclrool Bd., 73 Wis. 338, 243 N.W.2d 183 (1976), in which a batter's swing struck the plaintiff, next in lime to bat, in the face. Assumption of risk did 
of foreseeability of risks, with a concomitant increase in defendants' liability. Nabozny went even further in implying that injuries stemming from violations of safety rules are actionable, even if the violation was foreseeable. ${ }^{81}$

In summary, the defense of assumption of risk, a traditional bar to personal injury claims by participants in games and sports, is under attack. The doctrine never fully escaped its confused and inurky origins and is being phased out as a weapon in the defendant's arsenal. Although the debate over its usefulness will no doubt continue, the defense is, at least in sports-related personal injury actions, clearly in retreat.

Rudy Tomjanovich, in his suit against the Los Angeles Lakers, was the first professional athlete to benefit from this retreat. ${ }^{82} \mathrm{Al}$ though Tomjanovich is a landmark decision in the area of professional sports, the case is actually the next logical step in the history of personal injury actions in athletics. In Tomjanovich, the blow by Los Angeles Laker Kermit Washington was both violative of league rules and beyond the foreseeable contacts of the game. Regardless of how assumption of risk is defined, the defense could not prevent Tomjanovich from rccovering. Basketball is a contact sport, but it is not so violent that players can expect to incur injuries of either the nature or degree of those Tomjanovich received. The blow did not arise out of the normal pushing and shoving inherent in the gaine; if it had, the case would have been more difficult. If the issue in Tomjanovich is simply whether a safety rule was broken, hability is clear. If the issue is whether the risk was foreseeable, liability is still clear.

In Hackbart, however, which also involved a personal injury action by a professional athlete, the liabihty is less clear. Despite the assault on assumption of risk evidenced by Nabozny and Bourque, the district court in Hackbart defended that doctrine. ${ }^{83}$ Inplicitly, the court rejected section 50, comment b, of the Restatement (Second) of Torts, which ncgates the assumption of risk defense if the defendant has violated a safety rule. ${ }^{84}$ Although the defendant in Hackbart clearly violated a National Football League safety rule, ${ }^{85}$ the court paid

not, as a matter of law, bar the action. But see Richmond v. Employers' Fire Ins. Co., 298 So. 2d 118 (La. App.), cert. denied, 302 So. 2d 18 (La. 1974); Gaspard v. Grain Dealers Mutual Ins. Co.,

131 So. 2 d 831 (La. App. 1961).

81. See notes $72-77$ supra and accompanying text.

82. Bourque and Nabozny involved competitive but non-professional athletic contests.

83. 435 F. Supp. 352, 356 (D. Colo. 1977), rev'd, 601 F.2d 516 (10th Cir.), cert. denied, 441 U.S. 931 (1979).

84. Comment $\mathrm{b}$ is quoted at note 75 supra.

85. "All players are prohibited from strikmg on the head, face or neck with the heel, back or side of the hand, wrist, forearm, elbow or clasped hands." Official Rules of Professional Football, 
little attention to this fact, focusing instead on whether the blow delivered by the defendant "[could] be considered as 'part of the game.' "86 In so doing, the court used an approach similar to that in Bourque, ${ }^{87}$ but arrived at a different result. Despite evidence to the contrary, ${ }^{88}$ the court held that Clark's blow was "part of the game," and hence an assumed risk. It paid particular attention to the violent and emotional nature of the game, and to evidence that the blow, when viewed on game films, did not bother team management. ${ }^{89}$ The district court erred, however, in its analysis. A plaintiff must assume the particular risk that resulted in his injury for his claim to be barred.90 Discussions about the violent nature ${ }^{91}$ of the game miss the point. The single ques-

Rule 12, § 2, art. 1, sec. 1, subsection C, quoted in Hackbart v. Cincinnati Bengals, Inc., 601 F.2d 516, 521 (10th Cir.), cert. denied, 441 U.S. 931 (1979).

86. 435 F. Supp. at 356 . The phrase "part of the game" is used in Note, Consent in Criminal Law: Violence in Sports, 75 MicH. L. Rev. 148, 160 (1976), and is defined as the ideals of the gaine, plus any contact associated with those ideals. $I d$. The extent to which violence is tolerated is relevant. The Note dealt principally with violence in hockey.

This view is similar to that taken in Note, Violence in Professional Sports, 1975 WIs. L. REv. 771,787 , which also deals primarily with hockey. While there have been no civil actions arising froin that sport, there have been three crininal cases. The state of Minnesota brought the only Aınerican case, against Boston Bruin Dave Forbes. A hung jury resulted in a mistrial, and charges were dropped. See also Regina v. Maki, 10 C.R.N.S. 268 (Ont. Prov. Ct. 1970); Regina v. Green, 16 D.L.R.3d 137 (Ont. Prov. Ct. 1970). Both defendants in the Canadian cases were acquitted. In Note, Violence in Professional Sports, supra, the author takes the position that roughing, minor fighting, and highsticking, are "part of the game" of hockey, but that incidents such as the Forbes case, in which a player smashed an opponent's face with his stick and then pummeled him, are not. Only the latter situation should lead to civil and criminal charges. "In short, as conduct becomes more brutal, it resembles less the sport than something all persons are equally well-suited to judge." $Y d .785$.

87. See text accompanying note 78 supra.

88. See note 15 supra.

89. $435 \mathrm{~F}$. Supp. at 356 . The court stressed the "frequency of emotional outbursts" in the league, a result of the emotional pitch at which the game is played. Id. John Ralston, the Denver Broncos' head coach in 1973, testified that he seeks to instill in his players an emotional level equivalent to that of a father who meets the man who attempted to kill his family. $1 d$. at 355 .

90. See text accoinpanying notes $61-69$ supra.

91. Statistics reveal how violent the gane really is. "In a recent two-year period [1973-74 season], the 1040 players who started the NFL season-plus their replaceinents-suffered an average of 1101 injuries so severe that they had to be removed from the contest. One hundred and thirty-six underwent surgery." Hechter, The Criminal Law and Violence in Sports, 19 CRIM. L.Q. 425, 436-37 (1976-77). In his article, Hechter quotes from his interviews with professional football players. Dwight White, a Pittsburgh Steeler defensive end, said, "[If] you play the gane you assume certain liabilities ... . [Y]ou might get hurt or might get laned or your neck broken ... A All that is part of the game." Id. 438. White's comınents, however, undoubtedly refer to the injuries resulting from the actual playing of the game, and not to the type of blow Clark dehvered, away from the scene of the action. Hechter's article provides an interesting view of sports violence and the role of the judicial system.

For a critical view of the violence in professional football see Booth, Clark Booth at the Super Bowl, Death and Football, The Real Paper, Jan. 28, 1976, at 16, col. 4. 
tion to be answered is whether Hackbart assumed the risk of being hit from behind when the play had already passed him by. This blow was not one of the frequent and hence foreseeable violations of the rules that should bar a plaintiff from recovering. Rather, it was, as the court of appeals intimated, ${ }^{92}$ a reckless act of violence not assumed by a player. Reversing the district court was good sense. It was also good law, following recent precedent and the decline of the assumption of risk defense. The actual ground for reversal was the district court's holding that it lacked jurisdiction over the case. The Supreme Court's denial of certiorari on this issue ${ }^{93}$ left intact the Tenth Circuit's ruling that there was jurisdiction. ${ }^{94}$ The more interesting question concerns the liability of professional athletes for game-related injuries. ${ }^{95}$ On the

92. The court stated:

But it is highly questionable whether a professional football player consents or submits to injuries caused by conduct not within the rules, and there is no evidence which we have seen which shows this. ...

- . .

The general customs of football do not approve the intentional punching or striking of others. That this is prohibited was supported by the testimony of all of the witnesses. ... [O]ne football player cannot imtentionally inflict a serious injury on another. Therefore, the notion is not correct that all reason has been abandoned, whereby the only possible remedy for the person who has been the viction of an unlawful blow is retahation.

601 F.2d at 520-21.

93. 441 U.S. 931 (1979). See 28 U.S.C. $\$ 1254$ (1976), which allows the Supreme Court to hear cases from a circuit court on a writ of certiorari prior to the rendition of a final judgenent, at the Court's discretion.

94. The circuit court's analysis of the jurisdictional issue is very interesting. The court's use of Erie Railroad Co. v. Tompkins, 304 U.S. 64 (1938), is too strict an application of the law established in that case. The Hackbart court of appeals clained Erie prohibited federal courts from ever using public policy, absent approval by state law, as a basis for a decision. $601 \mathrm{~F} .2 \mathrm{~d}$ at 523. Therefore, the district court should not have invoked social policy as a basis for its decision. 1d. When a case is of first impression, however, or when state law is unclear, a federal district court is not precluded by Erie from making a ruling consistent with principles the court chooses to adopt. The circuit court's use of Flast v. Cohen, 392 U.S. 83 (1968), also seems inappropriate. In Flast, a taxpayer was given standing to enjoin the United States from spending federal funds to buy books for religious schools. The Hackbart court relied on Flast as support for the proposition that Hackbart should not be denied access to the federal forum, but Flast concerned constitutional rights and has been limited to its facts. See, e.g., United States v. Richardson, 418 U.S. 166 (1974) (Powell, J., concurring); DeFunis v. Odegaard, 416 U.S. 312 (1973); Laird v. Tatuin 408 U.S. 1 (1972); Sierra Club v. Morton, 405 U.S. 727 (1972).

It is true, however, that the Hackbart district court's exposition on social policies overlooked the right of an injured party to have access to the courts. See Colo. Const. art. II, $\S 6$. Thus, while the appellate court's use of Flast and Erie was not particularly appropriate, its reversal of the district court was correct.

95. The court of appeals in Hackbart required that the action be brought for reckless unisconduct, rather than for ordinary negligence. 601 F.2d at 524. Reckless misconduct "actually involves a risk substantially greater in magnitude than is necessary in the case of negligence." Id. See Restatement (SECOND) OF TORTS $\$ 500$ (1965). Knowledge of the greater risk distinguislies negligence froin reckless misconduct. Id. Lack of intent to cause the specific injury distinguishes reckless inisconduct froin intentionaI torts. Id. $\S 501$, comment $f$. Colorado has adopted section 
facts in Hackbart, however, this issue can be decided without great difficulty. The risk of Clark's blow, like that of Washington's in the Tomjanovich case, could not have been assumed. It was neither foreseeable nor "part of the game."

The mapplicability of the defense of assumption of risk in these cases does not resolve the broad question of how far courts should go in assessing hability agamst professional athletes. From an assumption of risk perspective the issue is whether the standard of the defense should be foreseeability, "part of the game," or section 50 of the Restatement. The section 50 standard - that all safety rule violations are actionable-must be rejected as too hiberal in its treatment of plaimtiffs. Foreseeable violations of game rules should not be actionable by a professional athlete. Although section 50 offers an easy determination of hability by setting up a bright line category of actionable torts, the test is too burdensome on defendant athletes. The best view mquires whether the risk is a "part of the game." This standard differs from the foreseeability test by avoiding the definitional problems inherent in the word foreseeability that have long haunted the law of torts. ${ }^{96}$ The "part of the game" standard would allow a plamtiff to recover even if his injury resulted from a foreseeable risk, as long as that risk was not one normally associated with the game. Thus, while Hackbart may have foreseen the blow he received, given the emotionalism of the game and the frustration of a losing player, the blow was not a "part of the game." The Hackbart district court was wise in adopting the "part of the game" standard, although it failed to apply that standard properly. 97

The blows received by Hackbart and Tomjanovich were not "part of the game[s]" played by those plaimtiffs, and each defendant clearly violated the rules of the respective sports. The blows resulted from extraordinary behavior on the part of the defendants and not from contact normal to the competition. Neither plaintiff assumed the risk of such a blow, and each had a vahid cause of action. But agamst whom should these actions be brought? Is the individual player liable for his conduct? Is his employer hable as well? In hight of the analysis above, the issue of employer hability poses particular difficulty. This is the issue that the next section of this Comment will address.

500. See, e.g., Steeves v. Smiley, 144 Colo. 5, 354 P.2d 1011 (1960); Coffman v. Godsoe, 142 Colo. 575, 351 P.2d 808 (1960); Pettingell v. Moode, 129 Colo. 494, 271 P.2d 1038 (1954); Fanstiel v. Wright, 122 Colo. 451, 222 P.2d 1001 (1950).

96. See text accompanying notes 113-20 infra.

97. See note 15 supra. 


\section{III. "SCOPE OF EMPloyment" and Sports Litigation: THE LIABILITY OF A TEAM FOR THE RECKLESS CONDUCT OF ITS Players}

If the conduct of a player is found to be actionable, the question arises whether his employer should be held accountable. Under the principle of vicarious liability, ${ }^{98}$ an employer is liable for the wrongs committed by an employee, if they were committed in the scope of employinent.99 What constitutes the scope of employment, and indeed, whether the phrase still represents the state of the law in employeremployee vicarious liability, is the center of much controversy. This section will focus upon the limited question of a team's liability for the reckless conduct of a player, addressing the scope of employment problem to determine what actions taken by a player are within that scope.

The only litigated professional sports case in the civil damages area is Tomjanovich, which, although decided by a federal court in Houston, mvolved California law. 100 The unusual position taken by California courts concerning vicarious liability is unhelpful in a broad analysis of employer liability for injuries inflicted by an employeegame participant. In Carr v. Wm. C. Crowell Co., ${ }^{101}$ the California Supreme Court, speaking through Justice Traynor, held that "if the injury resulted from a dispute arising out of the employment" 102 and if the employment required the employee to associate with third parties who precipitated the mjury, ${ }^{103}$ the einployer was liable. In adopting an "arising out of" standard, the court rejected "scope of employment" as the benchmark of liability. ${ }^{104}$ In California, an employer is responsible for third parties' injuries caused by an employee if the employee's actions in any way arise out of his job. Although Carr remaims the law of California, no other state has adopted such a broad scope of hability for an employer. ${ }^{105}$

98. For discussions of vicarious liability, see generally F. HARPER \& F. JAMES, supra note 43, ch. XXVI, \$§ 26.6-.8; W. Prosser, supra note 14, §70.

99. See Restatement (SECOND) OF Agency \& 219 (1958). But see Fields v. Sanders, 29 Cal. 2d 834, 180 P.2d 684 (1947); Carr v. Wm. C. Crowell Co., 28 Cal. 2d 652, 171 P.2d 5 (1946).

100. See Tomjanovich v. California Sports, Inc., No. 78-243 (S.D. Tex. Oct. 10, 1979), appeal docketed, No. 79-3889 (5th Cir. Dec. 3, 1979).

101. 28 Cal. 2d 652, 171 P.2d 5 (1946). Carr involved a fight between employees of two building contractors. The fight stemmed from an argument regarding the quality of work being performed and resulted in a head injury to the plaimtiff from a hammer thrown by the defendant's employee.

102. Id. at 654, 171 P.2d at 7 (emphasis added). See CAL. Civ. CodE $\$ 2338$ (West 1954).

103. $28 \mathrm{Cal} .2 \mathrm{~d}$ at $656,171 \mathrm{P} .2 \mathrm{~d}$ at 7 . On the facts of the case, the enunciated rule clearly led to the finding that the employer was liable to the imjured third party.

104. Id.

105. Note, Respondeat Superior and the Intentional Tort: A Short Discourse on How to Make Assault and Battery a Part of the Job, 45 U. CiN. L. REv. 235, 248 (1976). The Court of Appeals 
Given this unusually expansive rule of vicarious liability, it is not surprising that in Tomjanovich the Los Angeles Lakers were held liable for the blow delivered by einployee Kermit Washington. The injury to Tomjanovich clearly resulted from a dispute arising out of Washington's employment, and was not the result of a purely personal grievance unrelated to basketball. Under California law this is sufficient to lold the employer liable. The case was therefore not analyzed from a "scope of employment" perspective. "Scope of employinent" does, however, remam the standard by which employer hability is determined in the other forty-nine states. Thus, the imposition of liability on the Lakers in Tomjanovich is relatively unhelpful in dealing with the issue of vicarious liability more generally.

The majority position regarding vicarious hability is illustrated by the decision of the Missouri Supreme Court in Milazzo v. Kansas City Gas Co. ${ }^{106}$ The dispute in Milazzo, as in Carr, "arose out of" the employment of the defendant's employee. ${ }^{107}$ Unlike the employer-defendant in Carr, however, the employer in Milazzo was not held liable. ${ }^{108}$ The majority rule, under which Milazzo was decided, is that unless the employee is im some way furthering the interests of the einployer, he is not acting within the scope of his employment. Therefore, when the employee acts out of wholly personal motives, the employer is not liable. ${ }^{109}$

The Restatement (Second) of Agency repeatedly emphasizes the requirement that the employee be actmg to further in some way the interests of the employer in order for the latter to be held liable.110 Outside of Cahfornia, this is still the prevailing view. ${ }^{111}$ When the majority

for the Second Circuit, when using federal common law, has adopted a standard similar to California's. Id. See notes 116-18 infra and accompanying text.

106. 180 S.W.2d I (Mo. 1944). A meter reader assaulted a customer of the defendant gas company while reading the meter. The opinion does not clearly describe the details of the skirmish, but the dispute did, without doubt, arise out of the meter reader's employment. The plaintiff had questioned the defendant's employee about the accuracy of his readings, and the validity of the gas bills. The altercation arose from these questions.

107. See text accompanying notes 101-03 supra.

108. 180 S.W.2d at 7.

109. See Restatement (SeCOND) OF AgenCY $\$ \S 228-229,235,245$ (1958). lllustrative cases are cited in note 111 infra.

110. Section 228 of the RESTATEMENT provides that an act is within the scope of employment only if "it is actuated, at least in part, by a purpose to serve the master." Restatement (SECOND) OF AGENCY $\S 228$ (1958). See also id. $\$ \S 236,245$, comment $f$.

111. See, e.g., Pickering v. Daniel J. Keating Co., 460 F.2d 820, 823 (3d Cir. 1972); Oman v. United States, 179 F.2d 738, 741 (10th Cir. 1949); Avery v. United States, 434 F. Supp. 937, 942 (D. Conn. 1977); Cruikshank v. United States, 431 F. Supp. 1355, 1358 (D. Hawaii 1977); Vargas v. Correa, 416 F. Supp. 266, 272-73 (S.D.N.Y. 1976); Wright v. Globe Porcelain Co., 72 N.J. 
view is applied to the facts of the Hackbart case it may produce a result different from that in Tomjanovich. In Hackbart the court found that Clark inflicted the blow "out of anger and frustration."112 It is difficult to see low this blow can be said to liave been delivered to furtlier the interests of the employer. Clark did not intentionally injure an important player to lielp win a game. Rather, the blow by Clark arose out of a purely personal motive-the venting of anger. For sucli conduct the employer should not be liable.

Those who argue that conduct such as Clark's or Washington's ${ }^{113}$ ouglit to be attributable to the team because of the emotionalism that coaches instill in the players, ${ }^{114}$ inay fall into a classic catcli-22. If the conduct of the reckless defendant is a direct consequence of the employer's actions, the einployer is liable. But sucli conduct, if it inheres in the competition, slould also be foreseen by the injured plaintiff. Assuming for thic moment that foreseeability is the standard by whicli to measure assuinption of risk, ${ }^{115}$ those actions foreseen by the team are also those foreseen by the plaimtiff and accordingly assumed by him. Thus, conduct for which the team could be liable under agency law is conduct exempt from liability under the assumption of risk defense. This is true unless two different definitions of foreseeability are used. The Court of Appeals for the Second Circuit advocated sucli an approacl in Ira S. Bushey \& Sons v. United States. ${ }^{116}$ In holding the United States liable for the tortious conduct of a seaman, the Bushey court adopted a foreseeability test ${ }^{117}$ for vicarious liability, but distinguished that test from the foreseeability standard used to determine negligence. The court quoted a leading treatise to support its loolding that "what is reasonably foreseeable in this context [respondeat superior . . . . is quite a different thing from the foreseeably unreasonable risk of harm that spells negligence."118 The result in Bushey is similar

Super. 414, 418, 179 A.2d 11, 13 (App. Div. 1962). Contra, Ira S. Bushey \& Sons v. United States, 398 F.2d 167 (2d Cir. 1968).

112. 435 F. Supp. at 353.

113. For purposes of this discussion it is assumed that California law would not supply the basis for the decision in Tomjanovich.

114. See note 89 supra and accompanying text.

115. See text accompanying note 78 supra.

116. 398 F.2d 167 (2d Cir. 1968). A drunken seaman returning to his ship flooded Bushey's dry dock, partially sinking the dock and the ship. Bushey sued the United States for damages.

117. Id. at 171 .

118. Id. (quoting F. HARPER \& F. JAMES, supra note 43, at 1372). The treatise continues:

Further, we are not looking for that which can and should reasonably be avoided, but with the more or less inevitable toll of a lawful enterprise. The foresight that should impel the prudent man to take precautions is not the same measure as that by which he should perceive the harm likely to flow from his long-run activity . . . .

F. HARPER \& F. JAMES, supra note 43, at 1377. 
to the result of the California vicarious liability cases. ${ }^{119}$ In California an employee's tortious conduct, if it arises out of his employment, is sufficient to hold an employer hable. Under the Bushey court's analysis, such tortious conduct would also be sufficient to hold the employer liable simce the conduct is a foreseeable business event. How these various definitions of foreseeability differ when used in the different contexts of negligence, vicarious liability, and assumption of risk is a difficult question. It is also the reason this Comment cliooses to forego use of the foreseeability standard in assumption of risk. ${ }^{120}$

A court that holds a teain liable for an imjury to a participant athlete would reason as follows: The plaintiff has not assumed the risk arising out of the particular conduct, since the act was unforeseeable. The defendant team is hable, however, because its player's act was "an mevitable toll"121 of business and, lience, was foreseeable. Under this model the team is held to have foreseen the act, and to have prepared to handle it as a busmess expense. The plaintiff-player, however, has not foreseen the same act, since it is a coinplete departure from the rules, customs, and normal violations of the gaine. A court inust, then, give twisted definitions to the word foreseeability to allow a cause of action to be brought by a player agamst an opposing teain. If the possibility that the reckless misconduct of an employee will injure an opponent is an "inevitable toll" of business, it is incongruous to say at the same time that the athlete does not assune the risk of injury. To do so requires a court to deprive foreseeability of any consistent core ineaning at all and to bend the word to achieve the desired result in each context. So variable a definition obfuscates the law, and places too great a burden-that of an insurer-on an einployer. ${ }^{122}$ Although this approach avoids the catch-22 discussed above, ${ }^{123}$ the better solution is to hold the participant-defendant, but not the team, liable. If the participant-plaintiff can brimg an action, the act of the opponent is by definition, nil this inodel, not foreseeable. The act, therefore, should not be "an mevitable toll" of business, and the teain should not be held liable. In essence, the type of action that could result in employer liability should, at the same time, bar the plaintiff's action altogether, because it must have been foreseen.

As demonstrated in Part II, the "part of the gaine" standard is more appropriate than the foreseeability standard for the assumption

119. See notes 101-05 supra and accompanying text.

120. See text accompanying notes $96-97$ supra \& 124-27 infra.

121. F. HARPER \& F. JAMES, supra note 43 , at 1377.

122. The Bushey court acknowledged this in noting that "the fact that the defendant is better able to afford damages is not alone sufficient to justify legal responsibility." 398 F.2d at 171 .

123. See text accompanying notes 114-15 supra. 
of risk defense in sports injury cases. The blows to the plaintiffs in both Hackbart and Tomjanovich certainly do not satisfy the "part of the game" standard, 124 which is defined as the ideals of the game plus all contact associated with those ideals. ${ }^{125}$ It is a narrower standard of assumption of risk than foreseeability and permits recovery for acts that are not "part of the game," 126 even when those acts are foreseeable. Accordingly, a team could properly be held liable under a Bushey-California vicarious liability standard and a "part of the game" assumption of risk standard for certain foreseeable injuries without the court's getting mired in the definitional problems inherent under a foreseeability standard of assumption of risk. ${ }^{127}$ As the Tomjanovich decision indicates, if an act is not a part of the game and is therefore actionable, the employer is liable as long as the act is not the result of "personal malice, not engendered by the employment." 128 Since no personal malice was involved in Tomjanovich, the Lakers were correctly held liable. Thus, under the minority view of California and Bushey (in whicl negligence foreseeability differs from assumption of risk foreseeability), if the "part of the game" standard of assumption of risk is used, a player may properly sue an opposing teain without the use of conflicting definitions of foreseeability.

The majority view, under which the scope of employment test is the standard of vicarious liability, operates differently. It provides that when an employee acts for purely personal reasons and not to further the interests of the employer, his actions are not within the requisite scope even if they arise out of the employment. ${ }^{129}$ Two modern examples are Vargas v. Correa ${ }^{130}$ and Cruikshank v. United States. ${ }^{131}$ in Vargas, the court held that although a prison guard occupies a position in which the use of force can be expected, the employer is not liable when the actionable tort grows out of a dispute not directly related to the job. The court noted that any other decision would reduce the doc-

124. See text accompanying notes $95-97$ supra.

125. See note 86 supra.

126. See text accompanying notes $96-97$ supra.

127. See text accompanying notes 121-22 supra.

128. Carr v. Wm. C. Crowell Co., 28 Cal. 2d 652, 656, 171 P.2d 5, 8 (1946).

129. Restatement (SECOND) OF Agency $\$ \$ 228-229$ (1958). See note 110 supra.

130. 416 F. Supp. 266 (S.D.N.Y. 1976). Plaintiff, a prisoner, sued a prison guard for injuries resulting from a fight. The altercation occurred when the guard changed the channel on a television installed for the inmates. The prisoners protested and the fight between the litigants ensued.

131. 431 F. Supp. 1355 (D. Hawaii 1977). The Central Intelligence Agency had opened Cruikshank's correspondences to the Soviet Union and had monitored the mail of many people without judicial authority. For a case with facts and a holding similar to Cruikshank, see Avery v. United States, 434 F. Supp. 937 (D. Conn. 1977). Vargas, Cruikshank, and Avery all dealt with intentional torts. 
trine of respondeat superior to nothing more than a tool to hold the employer liable at all times. ${ }^{132}$ Similarly, in Cruikshank the court held that the employer is liable only "if the employee was motivated by a desire to lielp his employer . . .."133 These cases are in accord with, and follow the reasoning of, Milazzo ${ }^{134}$ in loolding that actions by the einployee, if not inotivated by a purpose to serve the employer, cannot result in employer liability. ${ }^{135}$ Comment $f$ to section 245 of the Restatement (Second) of Agency also takes this position. ${ }^{136}$

Thus, under the majority rule, the Cincinnati Bengals in Hackbart, as Clark's employer, should not be held liable for the torts of its employee. The Bengals are more likely to be insured, and are probably better able than Clark to afford the loss, but neither reason is sufficient to justify liability on the facts in Hackbart. Under the clear weight of authority, personal actions of an einployee that do not further the interests of the employer are not attributable to the employer; hence, the Bengals and other similarly situated teams in the future must be held not liable.

\section{Conclusion}

Merging the troublesome areas of assumption of risk and vicarious liability in personal injury actions in professional sports, an area previ-

132. 416 F. Supp. at 271-72.

133. $431 \mathrm{~F}$. Supp. at 1358 . The court added that the employer would also be liable "if it [were] fair to shift the loss from the victim to the employer." Id. However, this last part of the quotation does not deserve much credence. Employer liability would essentially be absolute, because it is generally easier for an insured employer to bear the loss than a victim. Furthermore, the Cruikshank court cites Bushey, but even Bushey does not make the employer an insurer. See note 122 supra and accompanying text. The significance of Cruikshank is that it supports the proposition that actions not undertaken to further the interests of the employer are the acts of the employee alone and do not give rise to employer liability. For a case that fully comports with this statement of the law, see Avery v. United States, 434 F. Supp. 937, 942 (D. Conn. 1977).

134. See notes 106-09 supra and accompanying text.

135. See Restatement (SeCOND) OF Agency $\$ 228$ (1958), which is in accord. See also note 110 supra.

136. Restatement (SECOND) OF AGENCY § 245 (1958) provides:

Use of Force.

A master is subject to liability for the intended tortious harm by a servant to the person or things of another by an act done in connection with the servant's employment, although the act was unauthorized, if the act was not unexpectable in view of the duties of the servant.

This position is then limited by comment $f$ of that section:

Servant actuated by personal motives. The hability of a master for the use of force by a servant is not prevented by the fact that the servant acts in part because of a personal motive, such as revenge. The master, however, is relieved from liability under the rule stated in this Section if the servant has no intent to act on his master's behalf, although the events from which the tortious act follows arise while the servant is acting in the employment and the servant becomes angry because of them. The fact that the servant acts in an outrageous manner or inflicts a punishment out of all proportion to the necessities of his master's business is evidence indicating that the servant has departed from the scope of employment in performing the act. 
ously untouched by courts, caused certain difficulties. ${ }^{137}$ A separate treatment of assumption of risk led to the conclusion that neither Hackbart nor Tomjanovich should be prevented from bringing a personal mjury action by an assumption of risk defense. A separate treatment of vicarious liability concluded that the Cincinnati Bengals in Hackbart should not be held liable for Clark's conduct. These issues, however, cannot be viewed separately in a lawsuit. They are intertwined and must be treated as such. Thus, court findings on the plaintiff's assumption of risk weigh lieavily in determining whether the employer is liable. To choose a "foreseeability" standard in assumption of risk is to invite confusion. The standard is too broad and should result in the team never being liable for tortious player conduct. The "part of the game" standard allows for a more straightforward analysis, regardless of whether the Bushey-California or majority rule of vicarious liability is used. Accordingly, the "part of the game" standard should be adopted.

Courts need not refrain froin entering the arena of sports litigation. They inust, however, refrain from confusing the area by blurring the issues involved. Proper standards can be applied to reach clear, legally correct decisions in this area. Professional sports litigation, although a new branch of law, is not without roots. The troublesome issues raised here can be handled as they have been handled in other areas of the law, such as amateur sports and games. Subject to certain restraints, to ensure that the game is played more on the field than in the courtroom, courts must provide a remedy for reckless conduct, whether it occurs on a field of play or elsewhere. Access to the courts cannot be denied to injured players like Hackbart and Tomjanovich. Players violating the "part of the game" standard should not be able to hide behind the defense of assumption of risk. It does not follow, however, that a team should necessarily also be liable. In fact, under the majority rule, a team sliould not be held liable for actions like those of "Booby" Clark and Kerınit Washington. The players themselves should be personally liable. Athletes today have pockets sufficiently deep to handle liability for their actions. If they do not, perliaps fear of financial loss will induce them to circumscribe their conduct. Certainly no sport will suffer if judicial involvement prevents future conduct like that of Washington and Clark.

Neil R. Tucker

137. This Comment is not concerned with the "justness" of the Bushey decision and its expansion of vicarious liability. Nor is its purpose to discuss the proper role of assumption of risk in tort law. Rather, this Comment seeks to explore the new area of tort liability in professional athletics, focusing on the issues most troublesome to this new field of law. 